\title{
Plankton Abundance and Physico-Chemical Water Quality of Effluent Impacted Water-Bodies in Ile-Ife, Nigeria
}

\author{
Adebukola A. ADEDEJI*, Joshua S. OLAJIDE, Tolulope I. ALUKO, \\ Iysa O. MUHIBBU-DIN
}

\author{
Obafemi Awolowo University, Faculty of Science, Department of Zoology, Ile-Ife, \\ Nigeria; bbkadedeji@oauife.edu.ng;jsolajide@yahoo.com;_israeltolulope@gmail.com; iysakola@gmail.com (*corresponding author)
}

\begin{abstract}
An effluent receiving stream and Opa River to which it drains within Obafemi Awolowo University, South-Western Nigeria, were studied to ascertain the level of physico-chemical and biological pollution. Water samples were collected and analysed using various standard methods for planktonic abundance and selected physico-chemical parameters over a period of seven months. Most of the water quality parameters investigated showed statistically insignificant differences between the stream and Opa River, except conductivity, nitrate and turbidity. Notable parameters were nutrient level indicator (conductivity, nitrate, organic matter, COD and planktonic abundance) whose mean concentrations were higher in the effluent receiving stream than Opa River. Even more, the seasonal variations of some of the investigated parameters (sulphate, organic matter and conductivity) at both sampled stations revealed the effect of anthropogenic run-off as additional source of dissolved nutrient and chemical enrichment rather than the effluent only. Highest occurrence of Chlorophyceae and abundance of Bacillariophyceae in the studied water bodies revealed a level of organic pollution, while the low occurrence species diversity of copepod, cladocera, diptera and protozoa further connotes the unfavourable physico-chemical condition of the water bodies. However, this effect was observed to be reduced at the point where the stream emptied into Opa River. Hence, the effect of the effluent discharge may not pose a health risk to several rural communities downstream which rely on the receiving water body primarily as their source of domestic water. Nevertheless, due to the level of organic pollution recorded, it could be suggested that the oxidation pond effluent discharge should be treated and/or recycled before discharge into this natural body of water.
\end{abstract}

Keywords: diversity, phytoplankton, pollution, river, stream, zooplankton

\section{Introduction}

The primary channels for waste disposal especially the effluents from industries, municipal waste seepages and oxidation pond effluents are flowing waters. Effluent, untreated or partially treated water usually has some concentration of nutrient, sediment and toxic substances which may have negative impact on the water quality and life forms of the receiving water (Forenshell, 2001; Schulz et al., 2003). Water effluents from oxidation ponds are known to have high concentration of ammonium, nitrate and phosphate ions as major constituents, hence when municipal wastes is discharged into water bodies usually alter the physico-chemical quality of water such as acidity (change in $\mathrm{pH}$ ), electrical conductivity, dissolved oxygen and temperature (Dwivedi and Pandey, 2002). Water bodies with effluent from various sources have also been reported to have a wide spectrum of organic and inorganic chemicals and pathogens (Okoh et al., 2007). These pathogens, when consumed by humans, especially in the developing countries where access to potable water is limited, could lead to illness and diseases (WHO, 2002).

Oxidation pond effluents alter physical, chemical and biological nature of receiving water body (Idris-Nda et al., 2013). The initial effect of waste is to degrade the physical quality of water. Later biological degradation becomes evident in terms of number, variety and organization of the living organism in the water (Gray, 1989). Zooplankton could be highly responsive to nutrient level, temperature, pollution and light intensity. Hence, the diversity of species, amount of biomass and abundance of zooplankton communities can be used to determine the health of an aquatic ecosystem (Havel et al., 2000). Whereas, the organic matter, a major component of oxidation pond effluent, promotes the growth of phytoplankton as well as macro benthic invertebrates (Adigun, 2005). Organic matter also stimulates the growth of decomposers such as bacteria and fungi. Bacteria and fungi are very critical to the breakdown 
170

of the toxic component of the effluent. Depletion of oxygen has been observed in effluent-receiving water bodies causing harmful substance to accumulate (Igbinosa and Okoh, 2009). Hence, plankton community are widely utilized as bio-indicator of environmental pollution because they respond quickly to environmental stresses (Dumont, 1999; Laura and Bohrer, 2008).

Therefore, contamination of water environment by effluent is viewed as an international problem because of the gross effect on the ecosystem. In Nigeria, the situation is no better by the activities of sewage discharge into streams and rivers. In the hereby study, the effluent-receiving stream and the river to which it empties, which both serve as source of water to some communities downstream, were analysed. The water is being used for a variety of purposes like irrigation, washing and other domestic uses, without prior treatment. The present study was to ascertain the plankton species-richness in the stream and also for the assessment of physicochemical parameters to uncover the level of ecological stress to which aquatic fauna and flora were exposed. Premised on this, the water quality of the effluentreceiving stream / river and planktonic diversity was monitored for seven months to establish its suitability for human uses.

\section{Materials and Methods}

\section{Study area}

This study was conducted on a stream receiving effluent from two waste stabilization ponds within Obafemi Awolowo University community (Latitudes $7^{\circ} 27^{\prime} \mathrm{N}$ to $7^{\circ} 32^{\prime} \mathrm{N}$ and Longitude $4^{\circ} 31^{\prime} \mathrm{E}$ to $\left.4^{\circ} 35^{\prime} \mathrm{E}\right)$. The stream serves as sink for the effluent from oxidation ponds in which the sewage of the university community is treated. Water samples were collected from two points along the course of the water body monthly from June to December 2010. The first sampled point was just about the point of effluent discharge into the stream (Latitude $007^{\circ} 30.326^{\prime} \mathrm{N}$ and Longitude $004^{\circ} 30.654^{\prime} \mathrm{E}$ at an altitude of $236 \mathrm{~m}$ ). The second sampled point was where the stream empties into Opa River (Latitude $007^{\circ} 30.378^{\prime} \mathrm{N}$ and Longitude $004^{\circ}$ $30.721^{\prime}$ E, altitude $250 \mathrm{~m}$ ).

\section{Sampling procedure}

Physicochemical parameters such as $\mathrm{pH}$, temperature, electrical conductivity, transparency and depth were determined in situ. Water samples for the analysis of DO and BOD were collected in $250 \mathrm{ml}$ glass bottles, while water samples for the analysis of other parameters were collected in 2 litres capacity plastic bottles. Before sampling, each bottle was washed with detergent followed by tap water and finally rinsed several times with distilled water. The water at each sampling stations were allowed to overflow for some time then the bottles were rinsed three times with sampling water and then 2 litres of water was collected. The collection was done midstream at a depth of $30 \mathrm{~cm}$ below the water surface. The samples were properly tagged, air tightened and stored in a refrigerator till complete analyses were carried out.

Plankton samples were collected by straining 15 litres of water through plankton net of mesh size $46 \mu \mathrm{m}$. The concentrated plankton volume was then put into specimen bottle and preserved with $5 \%$ formalin solution. Two drops of Lugol solution were added to the content of the bottle for precipitation of the concentrate.

\section{Physicochemical analysis}

The samples for the determination of dissolved oxygen (DO) were collected in $250 / 125 \mathrm{ml}$ capacity glass reagent bottles, fixed in the field using Winkler's reagents and were analysed in the laboratory by titration using Winkler's method. BOD5 samples were equally collected in glass reagent bottle, but were not fixed. Biological oxygen demand (BOD) water samples were kept in dark cupboard at room temperature $\left(25^{\circ} \mathrm{C}\right)$ for five days after which the oxygen content was determined titrimetrically (Ademoroti, 1996).

The analysis for sulphate, nitrate and turbidity were done by turbidimetric, brucine and colorimetric method respectively (Ademoroti, 1996). Chemical oxygen demand (COD) and organic matter determination were based on titrimetric method using potassium dichromate as oxidizing agent and Iron (II) ammonium as reducing agent.

\section{Planktonic analysis}

The counting chamber was filled with $1.5 \mathrm{ml}$ of the sample using pipette after decanting the supernatant. The counting chamber was covered with clean glass slide and examined under light microscope using $\times 100$ objective lens. The species of plankton encountered were counted and identification was based on their morphological characteristic using the work of Fernando (2002), Reynold (2006), Brierley et al. (2007), Suthers and Rissik (2009), Bellinger and Sigee (2010). The number of individual plankton species per $\mathrm{m}^{3}$ was evaluated by the relation:

$$
\mathrm{N}={ }^{n c} / V \times 1000
$$

Where $\mathrm{N}=$ number of each species per litre, $\mathrm{n}=$ abundance of the species in the counting chamber, $\mathrm{c}=$ concentrate volume of water used, $1.5 \mathrm{ml}, \mathrm{V}=$ original volume of water sampled ( 15 litters).

\section{Data analysis}

Data were subjected to appropriate statistical methods including descriptive statistics, correlation analysis and t-test to assess the difference in the effect of the effluent discharge on water quality and planktonic assemblage of the sampled stream and Opa River using SPSS package (Version 21; SPSS Inc. 2012). Inter-relationship among / between physico-chemical factors and planktonic abundance was determined using PAST (Paleontological Statistics) Statistical software version 2.12.

\section{Results and Discussion}

\section{Physico-chemical variables}

The results showed that water temperature ranged from $17^{\circ} \mathrm{C}$ to $23^{\circ} \mathrm{C}$ and $18^{\circ} \mathrm{C}$ to $26^{\circ} \mathrm{C}$ in the stream and Opa River respectively. The temperature profile of the effluentreceiving stream and River Opa to which it empties did not vary significantly (Table 1 ). The temperature range did not 
Table 1. Spatial variations in the physico-chemical water quality parameters, planktonic composition and abundance of the water bodies investigated

\begin{tabular}{|c|c|c|c|c|c|c|}
\hline \multirow{2}{*}{ Parameters } & \multicolumn{2}{|c|}{ Stream } & \multicolumn{2}{|c|}{ River } & \multirow{2}{*}{$\mathrm{F}$} & \multirow{2}{*}{$\mathrm{P}$ - ratio } \\
\hline & Range & Mean \pm S.D. & Range & Mean \pm S.D. & & \\
\hline Dissolved Oxygen (mg/l) & $3.20-11.60$ & $6.40 \pm 2.84$ & $4.00-13.6$ & $7.97 \pm 3.51$ & 0.545 & 0.475 \\
\hline Biological Oxygen Demand (mg/l) & $0.40-6.00$ & $2.06 \pm 1.96$ & $1.60-9.20$ & $4.40 \pm 2.67$ & 0.708 & 0.417 \\
\hline Temperature $\left({ }^{0} \mathrm{C}\right)$ & $17-23$ & $20.71 \pm 2.22$ & $18-26$ & $21.29 \pm 3.04$ & 1.987 & 0.184 \\
\hline Depth (m) & $0.21-0.34$ & $0.27 \pm 0.05$ & $0.48-1.10$ & $0.81 \pm 0.22$ & 7.378 & $0.019^{* *}$ \\
\hline Turbidity (NTU) & $86.00-97.00$ & $91.14 \pm 4.22$ & $90-94$ & $91.71 \pm 1.38$ & 6.485 & $0.026^{*}$ \\
\hline Conductivity $\left(\mu \mathrm{Scm}^{-1}\right)$ & $133-450$ & $301.43 \pm 102.42$ & $185-234$ & 209.7118 .91 & 7.704 & $0.017^{*}$ \\
\hline Alkalinity $\left(\mathrm{CaCO}_{3} \mathrm{mg} / \mathrm{L}\right)$ & $18-122$ & $56.57 \pm 40.23$ & $50-78$ & $63.14 \pm 9.79$ & 9.807 & $0.009^{* *}$ \\
\hline Acidity $\left(\mathrm{CaCO}_{3} \mathrm{mg} / \mathrm{L}\right)$ & $8-146$ & $58.00 \pm 58.42$ & $14-130$ & $68.86 \pm 47.86$ & 0.740 & 0.407 \\
\hline $\mathrm{pH}$ & $6.65-7.45$ & $6.91 \pm 0.32$ & $6.85-7.48$ & $7.06 \pm 0.23$ & 0.986 & 0.340 \\
\hline Nitrate (mg/l) & $0.10-0.75$ & $0.37 \pm 0.24$ & $0.10-0.20$ & $0.11 \pm 0.38$ & 10.987 & $0.006^{* *}$ \\
\hline Sulphate $(\mathrm{mg} / \mathrm{l})$ & $5.53-35.48$ & $16.96 \pm 12.06$ & $3.46-42.54$ & $19.21 \pm 15.42$ & 1.095 & 0.316 \\
\hline Organic matter $(\mathrm{mg} / \mathrm{l})$ & $1.29-3.38$ & $2.58 \pm 1.01$ & $0.52-4.65$ & $2.25 \pm 1.60$ & 2.490 & 0.141 \\
\hline Chemical Oxygen Demand (mg/l) & $2.00-6.00$ & $4.00 \pm 1.57$ & $0.80-7.20$ & $3.49 \pm 2.48$ & 2.518 & 0.139 \\
\hline Phytoplankton number & $7-23$ & $16 \pm 5$ & $9-23$ & $15 \pm 6$ & 1.334 & 0.271 \\
\hline Zooplankton number & $11-19$ & $16 \pm 3$ & $7-22$ & $16 \pm 6$ & 2.324 & 0.153 \\
\hline Phytoplankton abundance (org/L) & $11,400-974,500$ & $172,415 \pm 354,241$ & $4,200-480,200$ & $93,286 \pm 171,419$ & 1.241 & 0.287 \\
\hline Zooplankton abundance (org./L) & $14,600-62,000$ & $30,000 \pm 18,057$ & $6,800-35,400$ & $24,572 \pm 10,907$ & 1.455 & 0.251 \\
\hline
\end{tabular}

pose any threat to the homeostatic balance of the receiving water bodies as the values were in agreement with the report of DWAF, (1996) in which the recommended limit for no risk was set between $25^{\circ} \mathrm{C}$ and $40{ }^{\circ} \mathrm{C}$. However, water temperature was found to be lower at the effluent discharge point than in the river. This was overtly incoherent with the report of Anyinkeng et al. (2016) from water bodies affected with anthropogenic activities in which the temperature of the water at the discharge point and other physicochemical properties were higher than values recorded downstream. This could have been as a result of the vegetation cover that characterised this sampled station.

The mean values of conductivity and turbidity showed significant $(p<0.05)$ variations between the stream and the river (Table 1). Higher conductivity was observed at the effluent discharge point (the stream) than in the Opa River indicating higher nutrient ions. Electrical conductivity is a useful indicator of mineralization and salinity in water. The recorded conductivity in the stream exceeded FEPA acceptable limit of $70 \mu \mathrm{Scm}^{-1}$ (DWAF, 1996) making the stream unsuitable for direct domestic use. The conductivity values in the River were however less than $400 \mu \mathrm{Scm}^{-1}$ thus of poor ionic concentration (Kemdirim, 2005) and can be classified as mesotrophic (Garg et al., 2010), which could support diverse species of organisms. The turbidity values obtained from the waterbodies were also higher than WHO standard of 5 NTU (WHO, 2004) and FEPA guideline of 0 to 1 NTU for turbidity of water for domestic use (DWAF, 1998). The significantly varied turbidity profiles $(\mathrm{p}<0.05)$ between the two sampled sites was as reported by Igbinosa and Okoh (2009) from a treated wastewater effluent discharge receiving watershed in a rural community of Eastern Cape Province of South Africa. The higher turbidity of the stream, however, could also be linked to its shallowness as compared to the river. Moreover, mean values of nitrate, organic matter and COD were higher in the effluent receiving stream than the river, just as Anyinkeng et al. (2016) also reported in water bodies impacted with anthropogenic waste.

The mean values of $\mathrm{pH}$ at the stream (6.65-7.45) and in the river $(6.85-7.48)$ were found to be within the stipulated
Nigerian FEPA pH limit of between 6.0 and 9.0 for effluent discharge from sewer into water body (Ogunfowokan, 2005).

Overlaps were observed in the range of all the physicochemical parameters investigated in the two sampled stations, except depth (Table 1). With the recorded values of DO (4.00-13.6 $\left.\mathrm{mgL}^{-1}\right)$, BOD (1.60-9.20 $\left.\mathrm{mgL}^{-1}\right)$, sulphate $\left(3.46-42.54 \mathrm{mgL}^{-1}\right)$, organic matter $\left(0.52-4.65 \mathrm{mgL}^{-1}\right)$ and COD (0.80-7.20 $\left.\mathrm{mgL}^{-1}\right)$ having a wider mean range in Opa River than the stream. Conversely, wider range of turbidity (86-97.00 NTU), conductivity $\left(133-450 \mu \mathrm{Scm}^{-1}\right), \mathrm{pH}$ (6.65-7.45), Nitrate (0.1-0.75 $\left.\mathrm{mgL}^{-1}\right)$, phytoplankton species, and planktonic abundance were recorded in the effluent receiving stream. Some of the DO values recorded from this study fell short of recommended standard of 6 $\mathrm{mgL}^{-1}$ for domestic use and $4-5 \mathrm{mgL}^{-1}$ for sustaining fish and aquatic life as reported by Rao (2005), as well as EU guidelines (Momba et al., 2006) for the protection of aquatic ecosystems in both the investigated river and stream. Low dissolved oxygen has equally been reported to be deleterious to most aquatic fauna, revealing anoxic condition from organic-rich effluent of polluted water (Kshirsagar et al., 2012). DO values in unpolluted water normally range between 8 and $10 \mathrm{mg} / \mathrm{l}$ and concentrations below $5 \mathrm{mg} / \mathrm{l}$ affect aquatic life (Momba et al., 2006). The BOD levels recorded in the Opa River was higher (Table 1), suggesting other sources of organic pollution.

In this study, the nitrate concentrations differed significantly $(\mathrm{p}<0.01)$ (Table 1$)$ between the two stations, being higher in the stream than Opa River, suggesting that the effluent could be a source of eutrophication for receiving water bodies as the obtained values exceeded the most common natural concentration $\left(0.01 \mathrm{mgL}^{-1}\right)$ as compiled by Meybeck cited Chapman et al. (1996). The diverse group and relatively wide-ranged abundance of the phytoplankton species recorded in the stream suggested an irregularity in its chemical composition.

The highest mean value of conductivity (301.43 $\left.\mu \mathrm{Scm}^{-1}\right)$, nitrate $\left(0.37 \mathrm{mgL}^{-1}\right)$, organic matter $\left(2.58 \mathrm{mgL}^{-1}\right)$ and COD $\left(4.00 \mathrm{mgL}^{-1}\right)$ recorded in the stream resulted in the maximum mean abundance of phytoplankton $(172,415$ 

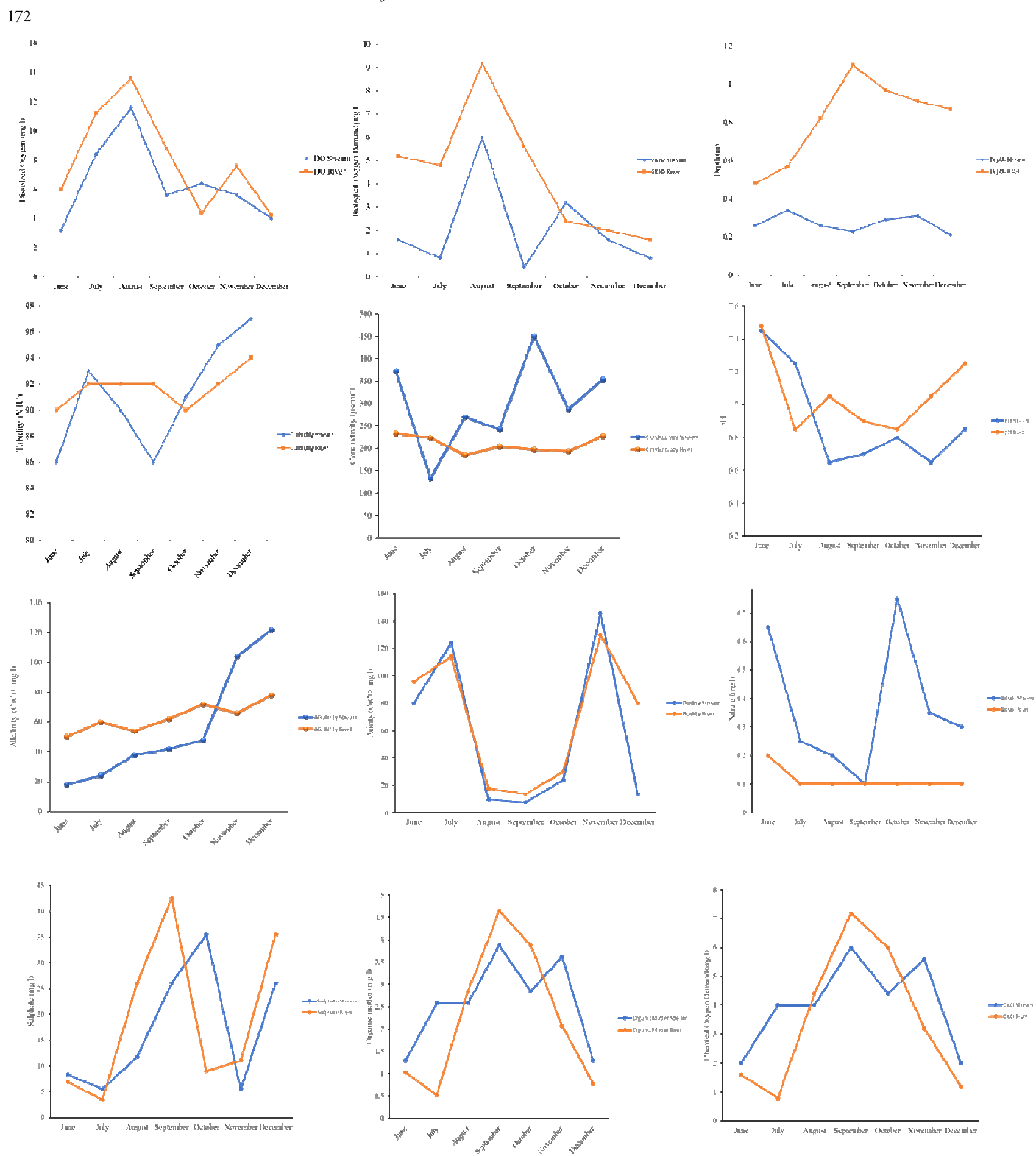

Fig. 1. Temporal variation in the physico-chemical water quality parameter in the investigated water bodies

$\left.\operatorname{orgm}^{-3}\right)$ and zooplankton $\left(30,000\right.$ orgm $\left.^{-3}\right)$ at this discharge point. Moreover, according to Ogunfowokan et al. (2005), an increase in COD could be attributed to an increase in the addition of both organic and inorganic substance from the municipal sewage treatment plants which could have promoted the planktonic growth. It has also been previously reported by Morrison et al. (2001) and Fatoki et al. (2003) that the contribution of effluent to COD level of receiving water bodies in Nigeria appears to be significant.

Seasonal variation patterns recorded for conductivity and $\mathrm{pH}$ level from the sampled sites were similar and these decreased with rain (Fig. 1) probably due to dilution by runoff. While COD and organic matter increased with rainfall at both sampled stations (Fig. 1), the highest concentrations were recorded in September, signifying the influence of anthropogenic run-off other than the effluent on these parameters. Moreover, it was noted that conductivity reached the highest level in October and June in stream and Opa River respectively, connoting the two peaks of the rainy season. This difference in time could also be linked to other sources of dissolved nutrient/chemical enrichment than the effluent.

\section{Biological variables}

In the current study, 92 species of plankton were identified including 48 species of phytoplankton and 44 
species of zooplankton. Out of the 48 species of phytoplankton recorded from the two sites, 36 species were common to both sites. The identified phytoplankton species belonged to eight classes namely Bacillariophyceae, Chlorophyceae, Crysophyceae, Cyanophyceae, Dictyophyceae, Dinophyceae, Euglenophyceae and Xanthophyceae. The highest occurrence of Chlorophyceae in both sites (Table 2 ) reflected a level of organic pollution, while dinoflagellates less-frequent occurrence was a pointer to a relatively high acidity and unfavourable condition of the water bodies (Onyema, 2013). 41 species of the phytoplankton were recorded from the stream, of which 6 species comprising Skeletonema sp., Phaeocystis antantica (Class Bacillariophyceae), Characium gracilipipes (Class Dinophyceae), Euglena limnophila (Class Euglenophyceae), Goniochloris sculpta (Class Xanthophyceae), Aphanotheca clathrata (Class Cynophyceae) were only recorded at this site. Five out of 43 species of phytoplankton identified from Opa River were also found only in the River. These included Stephanochscus sp. (Class Bacillariophyceae), Ulothrix zonata, Anabaenopsis arnoldii, Euplotes sp. (Class Chrysophyceae) and Rivularia sp. (Class Dionphyceae). Bacillariophyceae and Chlorophyceae had the highest abundance in the stream and river respectively (Table 3), with Bacillariophyta being the most abundant division from this study, just as they are known to be common to Nigerian freshwater (Anyinkeng et al., 2016).

The distribution of Diatom (Bacillariophyceae) reflected the average ecological condition of the effluent receiving stream as reported by Passy et al. (2004). The high number of diatom species at both sites might be due to immense nutrient, especially nitrate and phosphate, from the effluent discharge into the stream. The presence of Euglena species further connotes a level of organic pollution at the investigated stations. The present observation might also be influenced by the environmental factors such as temperature, $\mathrm{pH}$, transparency and dissolved oxygen and phosphate that stimulated phytoplankton (algae) growth. However, the community structure is in line with Frankovick et al. (2006) assertion that the epiphytic diatom assemblage of the Florida Bay Estuary was structured by nutrient availability.

The zooplankton species observed from the two sampled sites belong to 3 phyla namely Rotifera, Arthropoda and Protozoa. Brachionus rubens, keratella tecta (Class Eurotatoria, Family Brachionidae) and Nauplius larva (Class Brachiopoda, Family Sididae) were recorded only in the Opa River, while Notholca sp. (Class Eurotatoria, Family Brachionidae) and Calanoid nauplius (Class Maxillopoda, Family Cyclopidae) were found only in the stream. Trichocerca similis was recorded throughout study period at the point of effluent discharge, followed by Filinia pejleri. Family Brachionidae has the highest abundance temporally and spatially. During the early months, Keratella valga, Lecane luna, Lecane leontina, Brachionus falcatus and Filinia pejleri (all of the Phylum Rotifera) had the highest abundance (3,400-10,200 orgm-3). Generally, from the two sites, Chaoborus sp., Trichocerca similis, Brachionus falcatus and Filinia pejleri were found to be abundant sequentially.
In the stream, phytoplankton showed higher abundance during the rainy months of June to September, while they showed higher abundance during the dry months in the river (Table 2). However, abundance of phytoplankton decreases with rain in the stream with members of the families of Chrysophyceae, Dinophyceae, Xanthophyceae, Dictyophyceae being absent in the stream by December. A gradual raise in abundance was observed in the zooplankton population of the sampled river through the rainy months. The increase in zooplankton abundance with rain has been attributed to flood discharge resulting in release of many organisms out of the river bed or littoral zone (Adeniyi and Adedeji, 2007). Meanwhile, the recorded overall plankton abundant in the stream than Opa River such that 6 out of 8 recorded phytoplankton families, and 4 out of 5 zooplankton groups, as well as higher planktonic abundance in the stream could be linked to nutrient constituent of the stream (Table 2).

Phytoplankton members of the Families Chlorophyceae, Cyanophyceae, Euglenophyceae were abundantly present in the months of July and August (Table 2). The highest abundance of plankton species was recorded in September and October. This could be attributed to the peak of rainfall and favourable physicochemical parameters due to dilution of water bodies which neutralised the toxic effect of the effluent. However, low percentage occurrence of zooplankton was recorded in dry season. This correlates with the findings of Onwudinjo and Egborge (1994), who observed that in dry season, when salinity is high, few species were distributed within the deeper water. Egborge (1981) reported that zooplankton abundance is maximum only in dry season. This negates the result of the hereby study, as more zooplankton species occurred in rainy season. Diptera were not found in the early months of sampling and were found more in the stream than the river except in October. This contradicts the report of Albert et al. (2016) from Ikpoba River where Diptera were more abundant between June and August. The low species diversity of copepod, cladocera, diptera and protozoans could be due to some unfavourable physicochemical conditions of the water-bodies like conductivity, turbidity and BOD (Edokpayi, 2010).

In the current study, there was highly significant positive correlation (Table 3 ) between DO and BOD ( $\mathrm{r}=0.692$, $\mathrm{p}=0.006)$, alkalinity and turbidity $(\mathrm{r}=0.670,0.009)$; phytoplankton number and sulphate $(r=0.728 ; p=0.003)$, as well as zooplankton with OM and COD ( $\mathrm{r}=0.777$, $\mathrm{p}=0.001$ ) (Table 3 ). The positive correlation of plankton with DO was earlier reported by Albert et al. (2016), which was attributed to importance of availability of nutrient for the thriving of the aquatic autotrophs and subsequently the heterotrophs. Significant negative correlation was observed between sulphate and acidity (0.686, p=0.007), zooplankton number and temperature $(\mathrm{r}=0.038, \mathrm{p}=0.014)$, as well as depth with conductivity and nitrate $(r=0.689$, $\mathrm{p}=0.006)$. Nutrient, especially nitrate, has been reported to correlate with phytoplankton abundance and this assertion was found valid from the study. Holmes (2015) also reported a significant correlation of diatom species abundance with nitrate and electrical conductivity. 
174

Table 2. Spatio-temporal variations in planktonic composition and abundance of the investigated water bodies

\begin{tabular}{|c|c|c|c|c|c|c|c|c|c|c|c|c|c|c|c|c|}
\hline \multirow{2}{*}{$\begin{array}{l}\text { Zooplankton } \\
\text { Phylum / Family }\end{array}$} & \multicolumn{2}{|c|}{ June } & \multicolumn{2}{|c|}{ July } & \multicolumn{2}{|c|}{ August } & \multicolumn{2}{|c|}{ September } & \multicolumn{2}{|c|}{ October } & \multicolumn{2}{|c|}{ November } & \multicolumn{2}{|c|}{ December } & \multicolumn{2}{|c|}{ Total } \\
\hline & Stream & River & Stream & River & Stream & River & Stream & River & Stream & River & Stream & River & Stream & River & Stream & River \\
\hline Rotifera & 61,400 & 40,800 & 45,200 & 29,400 & 23,200 & 34,000 & 4,200 & 16,300 & 8,800 & 2,600 & 7,400 & 4,200 & 29,800 & 1,800 & 158,000 & 107,600 \\
\hline Cladocera & 600 & 800 & 2200 & 400 & 2,000 & 2,400 & 3,000 & 5,200 & 4,000 & 5,400 & 4,600 & 7,000 & 600 & 7,000 & 15,200 & 21,200 \\
\hline Copepoda & - & - & 400 & - & 2,000 & 800 & 3,400 & 4,400 & 2,200 & 4,200 & 4,400 & 1,400 & 2,600 & 1,400 & 15,000 & 12,800 \\
\hline Protozoans & - & - & - & - & 800 & - & 1,400 & 1,000 & 3,000 & 2,000 & 2,200 & 2,400 & 1,600 & 2,400 & 9,000 & 5,800 \\
\hline Diptera & - & - & - & - & 1,600 & 400 & 3,600 & 800 & 1,800 & 600 & 2,400 & 1,000 & 1,600 & - & 11,000 & 2,800 \\
\hline TOTAL & 62,000 & 41,600 & 47,800 & 29,800 & 29,600 & 37,200 & 15,600 & 26,900 & 19,800 & 14,200 & 21,000 & 15,000 & 36,200 & 12,600 & 208,200 & 150,200 \\
\hline $\begin{array}{l}\text { Number of } \\
\text { species }\end{array}$ & 13 & 10 & 18 & 15 & 16 & 21 & 14 & 22 & 19 & 21 & 19 & 16 & 11 & 7 & 41 & 43 \\
\hline Phytoplankton & \multicolumn{2}{|c|}{ June } & \multicolumn{2}{|c|}{ July } & \multicolumn{2}{|c|}{ August } & \multicolumn{2}{|c|}{ September } & \multicolumn{2}{|c|}{ October } & \multicolumn{2}{|c|}{ November } & \multicolumn{2}{|c|}{ December } & \multicolumn{2}{|c|}{ Total } \\
\hline Family & Stream & River & Stream & River & Stream & River & Stream & River & Stream & River & Stream & River & Stream & River & Stream & River \\
\hline Bacillariophyceae & 6,500 & 200 & 13,900 & 14,400 & 7,800 & 1,000 & 1,400 & 2,400 & 5,600 & - & 7,600 & 5,200 & 11,100 & 2,800 & 53,900 & 26,000 \\
\hline Chlorophyceae & 800 & 400 & 6,450 & 4,200 & 3,000 & 3,600 & 1,400 & 6,000 & 600 & 4,800 & 2,400 & 6,800 & 400 & 7,000 & 15,050 & 32,800 \\
\hline Cyanophyceae & 3,200 & 1,600 & 13,500 & 1,800 & 14,000 & 6,400 & - & 400 & 1,200 & 4,200 & - & 400 & 600 & 600 & 32,500 & 15,400 \\
\hline Euglenophyceae & 1,400 & 1,000 & 2,700 & 8,100 & 9,000 & 4,600 & 2,000 & 1,000 & 11,400 & - & 200 & 400 & - & 1,000 & 26,700 & 16,100 \\
\hline Chrysophyceae & - & - & - & - & - & - & 800 & 800 & 200 & - & 200 & 2,000 & - & 1,600 & 1,200 & 4,400 \\
\hline Dinophyceae & - & - & - & - & - & 200 & - & 600 & 1,800 & 400 & - & - & - & - & 1,800 & 1,200 \\
\hline Xanthophyceae & - & - & 4,800 & - & 3,400 & 1,000 & - & 2,200 & 2,400 & - & - & 200 & - & 600 & 10,600 & 4,000 \\
\hline Dictyophyceae & - & - & - & - & 6,200 & 600 & - & 600 & - & - & 7,000 & - & - & - & 13,200 & 1,200 \\
\hline TOTAL & 11,900 & 3,200 & 41,350 & 28,500 & 43,400 & 17,400 & 5,600 & 14,000 & 23,200 & 9,400 & 17,400 & 15,000 & 12,100 & 13,600 & 154,950 & 101,100 \\
\hline $\begin{array}{l}\text { Number of } \\
\text { Species }\end{array}$ & 7 & 10 & 15 & 9 & 17 & 23 & 11 & 19 & 23 & 10 & 14 & 14 & 16 & 22 & 40 & 43 \\
\hline
\end{tabular}

Table 3. Correlation between the investigated physico-chemical parameters and the planktonic occurrence and abundance

\begin{tabular}{|c|c|c|c|c|c|c|c|c|c|c|c|c|c|c|c|c|}
\hline Parameters & DO & BOD & TEMP & DEPH & TURB & COND & ALKT & ACDT & NITR & SULP & ORGM & COD & P.NO & Z.NO & P.ABD & Z.ABD \\
\hline DO & 1.000 & & & & & & & & & & & & & & & \\
\hline BOD & $\begin{array}{c}0.692 \\
0.006\end{array}$ & 1.000 & & & & & & & & & & & & & & \\
\hline TEMP & $\begin{array}{c}-0.224 \\
0.440\end{array}$ & $\begin{array}{l}0.044 \\
0.883\end{array}$ & 1.000 & & & & & & & & & & & & & \\
\hline DEPTH & $\begin{array}{l}0.302 \\
0.294\end{array}$ & $\begin{array}{l}0.449 \\
0.107\end{array}$ & $\begin{array}{l}-.151 \\
.606\end{array}$ & 1.000 & & & & & & & & & & & & \\
\hline TURB & $\begin{array}{l}0.012 \\
0.967\end{array}$ & $\begin{array}{l}-0.196 \\
0.503\end{array}$ & $\begin{array}{l}-.405 \\
.151\end{array}$ & $\begin{array}{l}.144 \\
.623\end{array}$ & 1.000 & & & & & & & & & & & \\
\hline COND & $\begin{array}{c}-0.499 \\
0.069\end{array}$ & $\begin{array}{c}-0.203 \\
0.486\end{array}$ & $\begin{array}{l}.215 \\
.460\end{array}$ & $\begin{array}{c}-.708^{*} \\
.005\end{array}$ & $\begin{array}{l}-.181 \\
.536\end{array}$ & 1.000 & & & & & & & & & & \\
\hline ALKT & $\begin{array}{c}-0.268 \\
0.353\end{array}$ & $\begin{array}{l}-0.086 \\
0.770\end{array}$ & $\begin{array}{l}-.284 \\
.325\end{array}$ & $\begin{array}{l}.337 \\
.239\end{array}$ & $\begin{array}{c}0.670^{*} \\
0.009\end{array}$ & $\begin{array}{l}.055 \\
.852\end{array}$ & 1.000 & & & & & & & & & \\
\hline ACDT & $\begin{array}{c}-0.064 \\
0.828\end{array}$ & $\begin{array}{c}-0.150 \\
0.610\end{array}$ & $\begin{array}{l}-.179 \\
.540\end{array}$ & $\begin{array}{l}.314 \\
.274\end{array}$ & $\begin{array}{l}.358 \\
.208\end{array}$ & $\begin{array}{l}-.247 \\
.395\end{array}$ & $\begin{array}{l}.174 \\
.552\end{array}$ & 1.000 & & & & & & & & \\
\hline NITR & $\begin{array}{c}-0.332 \\
0.247\end{array}$ & $\begin{array}{l}-0.246 \\
0.397\end{array}$ & $\begin{array}{l}.007 \\
.981\end{array}$ & $\begin{array}{r}-0.646 \\
0.013\end{array}$ & $\begin{array}{l}.048 \\
.871\end{array}$ & $\begin{array}{l}.698^{*} \\
.006\end{array}$ & $\begin{array}{l}-.254 \\
.381\end{array}$ & $\begin{array}{l}.148 \\
.613\end{array}$ & 1.000 & & & & & & & \\
\hline SULP & $\begin{array}{c}-0.028 \\
0.925\end{array}$ & $\begin{array}{l}0.130 \\
0.657\end{array}$ & $\begin{array}{l}.293 \\
.310\end{array}$ & $\begin{array}{l}.086 \\
.769\end{array}$ & $\begin{array}{l}.018 \\
.951\end{array}$ & $\begin{array}{l}.146 \\
.618\end{array}$ & $\begin{array}{l}.157 \\
.592\end{array}$ & $\begin{array}{r}-0.686 \\
0.007\end{array}$ & $\begin{array}{l}-.182 \\
.533\end{array}$ & 1.000 & & & & & & \\
\hline ORGM & $\begin{array}{l}0.149 \\
0.611\end{array}$ & $\begin{array}{l}0.051 \\
0.862\end{array}$ & $\begin{array}{l}. .415 \\
.140\end{array}$ & $\begin{array}{l}.135 \\
.646\end{array}$ & $\begin{array}{l}-.185 \\
.526\end{array}$ & $\begin{array}{l}-.110 \\
.707\end{array}$ & $\begin{array}{r}-.009 \\
.976\end{array}$ & $\begin{array}{l}-.376 \\
.185\end{array}$ & $\begin{array}{l}. .096 \\
.745\end{array}$ & $\begin{array}{l}.338 \\
.238\end{array}$ & 1.000 & & & & & \\
\hline COD & $\begin{array}{l}0.149 \\
0.611\end{array}$ & $\begin{array}{l}0.051 \\
0.862\end{array}$ & $\begin{array}{l}. .415 \\
.140\end{array}$ & $\begin{array}{l}.135 \\
.646\end{array}$ & $\begin{array}{r}-.185 \\
.526\end{array}$ & $\begin{array}{r}-.110 \\
.707\end{array}$ & $\begin{array}{r}-.009 \\
.976\end{array}$ & $\begin{array}{l}-.376 \\
.185\end{array}$ & $\begin{array}{l}-.096 \\
.745\end{array}$ & $\begin{array}{l}.338 \\
.238\end{array}$ & $1.000^{*}$ & 1.000 & & & & \\
\hline P.NO & $\begin{array}{l}0.352 \\
0.217\end{array}$ & $\begin{array}{l}0.275 \\
0.341\end{array}$ & $\begin{array}{l}.043 \\
.883\end{array}$ & $\begin{array}{l}.102 \\
.730\end{array}$ & $\begin{array}{l}.419 \\
.136\end{array}$ & $\begin{array}{l}-.060 \\
.840\end{array}$ & $\begin{array}{l}.157 \\
.593\end{array}$ & $\begin{array}{l}-.356 \\
.212\end{array}$ & $\begin{array}{l}.001 \\
.997\end{array}$ & $\begin{array}{c}0.728^{\prime \prime} \\
0.003\end{array}$ & $\begin{array}{l}.249 \\
.390\end{array}$ & $\begin{array}{l}.249 \\
.390\end{array}$ & 1.000 & & & \\
\hline Z.NO & $\begin{array}{l}0.507 \\
0.064\end{array}$ & $\begin{array}{l}0.419 \\
0.136\end{array}$ & $\begin{array}{r}-.638^{\circ} \\
.014\end{array}$ & $\begin{array}{l}.436 \\
.119\end{array}$ & $\begin{array}{l}.029 \\
.921\end{array}$ & $\begin{array}{l}-.359 \\
.207\end{array}$ & $\begin{array}{l}.026 \\
.928\end{array}$ & $\begin{array}{r}-.062 \\
.834\end{array}$ & $\begin{array}{r}-.117 \\
.691\end{array}$ & $\begin{array}{l}.122 \\
.678\end{array}$ & $\begin{array}{c}0.777^{*} \\
0.001\end{array}$ & $\begin{array}{c}0.777^{\prime \prime} \\
0.001\end{array}$ & $\begin{array}{l}.317 \\
.269\end{array}$ & 1.000 & & \\
\hline P.ABD & $\begin{array}{l}.275 \\
.341\end{array}$ & $\begin{array}{l}.084 \\
.775\end{array}$ & $\begin{array}{l}-.422 \\
.133\end{array}$ & $\begin{array}{l}.123 \\
.675\end{array}$ & $\begin{array}{l}.025 \\
.934\end{array}$ & $\begin{array}{l}-.103 \\
.725\end{array}$ & $\begin{array}{l}-.363 \\
.203\end{array}$ & $\begin{array}{l}.172 \\
.557\end{array}$ & $\begin{array}{l}.247 \\
.395\end{array}$ & $\begin{array}{l}. .168 \\
.566\end{array}$ & $\begin{array}{l}.102 \\
.730\end{array}$ & $\begin{array}{l}.102 \\
.730\end{array}$ & $\begin{array}{c}-.042 \\
.887\end{array}$ & $\begin{array}{l}.430 \\
.125\end{array}$ & 1.000 & \\
\hline Z.ABD & $\begin{array}{l}.451 \\
.106\end{array}$ & $\begin{array}{l}.376 \\
.186\end{array}$ & $\begin{array}{l}.140 \\
.633\end{array}$ & $\begin{array}{l}.009 \\
.976\end{array}$ & $\begin{array}{r}-.241 \\
.406\end{array}$ & $\begin{array}{r}-.187 \\
.523\end{array}$ & $\begin{array}{c}-0.657^{\circ} \\
0.011\end{array}$ & $\begin{array}{l}.264 \\
.361\end{array}$ & $\begin{array}{l}.244 \\
.400\end{array}$ & $\begin{array}{l}-.513 \\
.060\end{array}$ & $\begin{array}{l}-.132 \\
.652\end{array}$ & $\begin{array}{l}-.132 \\
.652\end{array}$ & $\begin{array}{l}-.240 \\
.408\end{array}$ & $\begin{array}{l}.207 \\
.477\end{array}$ & $\begin{array}{l}.508 \\
.064\end{array}$ & $\begin{array}{r}1.000 \\
\text { Z.ABD }\end{array}$ \\
\hline
\end{tabular}

KEY: DO-Dissolved Oxygen, BOD- Biological oxygen demand, DEPT- Depth, TURB- Turbidity, ALKT- Alkalinity, ACDT- Acidity, NITR- Nitrate, SULPSulphate, ORGM- Organic matter, COD-Chemical Oxygen Demand, P.NO- Phytoplankton number, Z.NO- Zooplankton abundance, P.ABD-Phytoplankton abundance, Z.ABD- Zooplankton abundance

\section{Conclusions}

The study revealed that the level of effluent pollutant in the water-body plays an important role in the distribution and abundance of the plankton in the stream. There was an adverse impact on some physiochemical parameter (nitrate, COD and conductivity) by the effluent discharge of sewage treatment plants. However, this effect was relatively reduced at the point where the stream emptied into Opa River. Hence, the effect of the effluent discharge may not pose a health risk to the several rural communities downstream which rely on receiving water body primarily as their source of domestic water. Though, it was obvious that the portion of the stream sampled was under ecological stress, therefore it could be suggested that the oxidation pond effluent discharge should be treated and/or recycled before discharge into this natural body of water. There is also a need for intervention of appropriate regulatory agencies to ensure qualitative monitoring and treatment of oxidation pond effluent.

\section{Acknowledgements}

Thankful applause to Prof. I. F. Adeniyi for the free access into hydrobiology laboratory of Zoology Department, Obafemi Awolowo University, Ile Ife, Nigeria.

\section{References}

Ademoroti CMA (1996). Environmental chemistry and toxicology. Foludex Press Limited Nigeria, Ibadan. 
Adeniyi IF, Adedeji AA (2007). The Rotifera fauna of Gongola River basin, Northeast Nigeria. Ife Journal of Science 9(1):1-16

Adigun BA (2005). Water quality management in aquaculture and freshwater zooplankton production for use in fish hatcheries. National Institute for Freshwater Fisheries Research, New Bussa, Niger State.

Albert CI, Godwin IA, Sandra UI (2016). Ecological assessment of brewery effluent impact on the macrobenthic invertebrates of Ikpoba River, Edo State, Nigeria. International Journal of Ecosystem 6(3):47-54.

Anyinkeng N, Afui MM, Tening AS, Che CA (2016). Phytoplankton diversity and abundance in water bodies as affected by anthropogenic activities within the Buea municipality, Cameroon. Journal of Ecology and the Natural Environment 8(7):99-114.

Bellinger GE, Sigee DC (2010). Freshwater algae: Identification and use as bio-indicators. John Wiley and Sons Ltd (1st ed), The Atrium, Southern Gate, Chichester, West Sussex, PO198SQ, UK.

Brierley B, Carvalho L, Davies S, Krokowski J (2007). Guidance on the quantitative analysis of phytoplankton in freshwater samples. Report to SNIFFER(Project WFD80), Edinburgh.

Chapman D (1996). Water quality assessments: a guide to the use of biota, sediments, and water in environmental monitoring. UNESCO/WHOUNEP, Chapman \& Hall, London. New York.

Dumont HJ (1999). Phylogeny, evolution and classification of the branchiopod(Crustacean). Hydrobiologia 412:191-212.

DWAF (1996). South African water quality guidelines: Domestic uses. (2nd ed) Department of Water Affairs and Forestry, Pretoria, Vol. 1: Domestic Water use.

DWAF (1998). Quality of domestic water supplies: assessment guide.1 (2nd ed), Department of Water Affairs and Forestry, Department of Health and Water Research Commission.

Dwivedi, BK, Pandey GC (2002). Physico-chemical factors and algal diversity of two ponds in Faizabad, India. Pollution Research 21(3):361-370.

Edokpayi CA, Olowoporoku AO, Uwadiae RE (2010). The hydrochemistry and macrobenthic fauna characteristics of an urban draining creek. International Journal of Biodiversity and Conservation 2(8):196-203.

Egborge ABM (1981). The composition, seasonal variation and distribution of zooplankton in lake Asejire, Nigeria. Revue Zoologique Africaine 95:137-165.

Fernando CH (2002). A guide to tropical freshwater zooplankton: identification, ecology and impact on fisheries. Backhuys Publishers, Leiden, The Netherlands.

Garg RK, Rao RJ, Uchchariya D, Shukla G, Saksena DN (2010). Seasonal variations in water quality and major threats to Ramsagar reservoir, India. African Journal of Environmental Science and Technology 4(2):061-076.

Havel JE, Eisenbacher EM, Black AA (2000). Diversity of crustacean zooplankton in riparian wetlands: colonization and egg banks. Aquatic Ecology 34(1):63-76.

Fatoki SO, Gogwana P, Ogunfowokan AO (2003). Pollution assessment in the Keiskamma River and in the impoundment downstream. Water South Africa 29 (3):183-187.
Forenshell G (2001). Setting Basin Design. Western Regional Aquaculture Center, WRAC-106. USA.

Frankovick TA, Gaiser EE, Zieman C, Wachnicka AW (2006). Spatial and temporal distributions of epiphytic diatoms growing on Thalassia testudinum Banks ex Konig: relationships to water quality. Hydrobiologia 569:259-271.

Gray AV (1989). Case study on water quality modelling of Dianchilake, Yunnan province, southwest China. Water Science Technology 40:35-43.

Holmes M, Taylor JC (2015). Diatoms as water quality indicators in the upper reaches of the Great Fish River, Eastern Cape, South Africa. African Journal of Aquatic Science 40(4):321-337.

Idris-Nda A, Aliyu HK, Dalil M (2013). The challenges of domestic wastewater management in Nigeria: A case study of Minna, central Nigeria. International Journal of Development and Sustainability 2 (2):1169-1182.

Igbinosa EO, Okoh AI (2009). Impact of discharge wastewater effluents on the physico-chemical qualities of a receiving watershed in a typical rural community International Journal of Environmental Science and Technology 6(2):175-182.

Kemdirim EC (2005). Studies on the hydrochemistry of Kangimi reservoir, Kaduna State, Nigeria. African Journal of Ecology 43:713.

Kshirsagar AD, Ahire ML, Gunale VR (2012). Phytoplankton diversity related to pollution from Mula river at Pune City. Terrestrial Aquatic and Environmental Toxicology 6:136-142.

Laura RP, Bohrer M (2008). Characterization of the zooplankton community of the waste water treatment system of an oil refinery in southern Brazil. Biociencias Porto Alegre 16(1):1-14.

Momba MNB, Osode AN, Sibewu M (2006). The impact of inadequate wastewater treatment on the receiving water bodies Case study: Buffalo City and Nkokonbe Municipalities of the Eastern Cape Province. Water Institute of South Africa 32(5):687692.

Morrison G, Fatoki OS, Persson L, Ekberg A (2001). Assessment of the impact of point source pollution from the Keiskammahoek Sewage treatment plant on the Keiskamma River - $\mathrm{pH}$, electrical conductivity, oxygen demanding substance (COD) and nutrients. Water South Africa 27(4):475-480.

Ogunfowokan AO, Okoh EK, Adenuga AA, Asubiojo OI (2005). Assessment of the impact of point source pollution from a University sewage treatment oxidation pond on the receiving stream-a preliminary study. Journal of Applied Science 6(1):36-43.

Okoh AI, Odjadjare EE, Igbinosa EO, Osode AN (2007). Wastewater treatment plants as a source of microbial pathogens in the receiving watershed. African Journal of Biotechnology 6(25):2932-2944.

Onwudinjo CC, Egborge ABM (1994). Rotifers of Benin River, Hydrobiologia 272:87-94.

Onyema IC (2013). Phytoplankton bio-indicators of water quality situations in Iyagbe Lagoon, South-Western Nigeria. Acta SATECH 4(2):93-107.

Passy SI, Bode RW, Carlson DM, Novak MA (2004). Comparative environmental assessment in studies of benthic diatom, macroinvertebrate, and fish community. International Review of Hydrobiology 89:121-138. 
176

Rao PV (2005). Environmental engineering. Eastern Economy Ed. Prentice-Hall of India Private Limited, New Delhi.

Reynold CS (2006). The ecology of phytoplankton. (1st ed), Cambridge Publishers, New York.

Schulz C, Gelbrecht J, Rennert B (2003). Treatment of rainbow trout farm effluents in constructed wetland with emergent plants and subsurface horizontal water flow. Aquaculture 217(1-4):207-221.

Suthers LM, Rissik D (2009). Plankton: A guide to their ecology and monitoring for water quality. CSIRO Publishing, Oxford University Press, London.
WHO (2002). Water and health in Europe: A joint report from the European Environment Agency and the WHO Regional Office for Europe. World Health Organization, WHO Regional Publications, European Series No 93.

WHO (2004). Rolling revision of the WHO guidelines for drinkingwater quality, Draft for review and comments. Nitrates and Nitrite in drinking water. World Health Organization (WHO/SDE/WHW/04/08/05). 